\section{GALLIS MAGIS QUAM ROMANIS SIMILES: OS IRMÃOS FÁBIOS E O TRÁGICO DESTINO DE ROMA (LÍVIO, AB URBE COND., V, 35-39)}

\author{
Priscilla Adriane Ferreira Almeida* \\ Recebido em: 31/10/2018 \\ Aprovado em: 24/01/2019
}

\begin{abstract}
RESUMO: Este artigo pretende analisar o papel desempenhado pelos irmãos Fábios em Lívio, V, 35-39, e como a conduta deles de alguma forma contribuiu para o trágico destino de Roma, que foi saqueada pelos gauleses. Entre os capítulos V, 35-36, Lívio narrou o ataque gaulês à cidade de Clúsio. Os romanos, chamados para ajudar, enviaram os irmãos Fábios como emissários, a fim de tentar um acordo de paz com os invasores. Essa tentativa, contudo, tornou-se um grande fracasso, já que os Fábios desrespeitaram o direito das nações e atacaram os gauleses. Levando em consideração essa terrível atitude praticada pelos Fábios e o iminente saque de Roma dentro da narrativa liviana, este artigo analisa o papel da Fortuna (sorte) nos acontecimentos descritos em Lívio, V, 36-39. Além disso, discute-se a conduta desonrosa dos romanos, entre V, 37-38, que culminou na derrota deles, próximo ao rio Ália. Por fim, esse artigo examina a maneira como Lívio desenvolveu cada episódio em V, 39 como uma reconquista da virtude romana, com exemplos de coragem do povo romano e respeito aos deuses, outrora desprezados. São realizados ainda um estudo dos elementos retóricos e literários empregados por Lívio para caracterizar romanos e gauleses e retratar os fatos ocorridos, bem como a análise de alguns conceitos-chave, como fides, pietas, concordia e mos maiorum.
\end{abstract}

PALAVRAS-CHAVE: Lívio; saque de Roma; retórica; moral; Fortuna.

\section{GALLIS MAGIS QUAM ROMANIS SIMILES: THE FABII BROTHERS AND THE TRAGIC DESTINY OF ROME ( LIVY, AB URBE COND., 5.35-39)}

* Doutora pelo Programa de PósGraduação em Estudos Literários, Faculdade de Letras, Universidade Federal de Minas Gerais. prisadriane@gmail.com

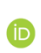


chapters 5.35-36, Livy narrated the Gauls' attack on the city of Clusium. The Romans, called to help, sent the Fabii brothers as emissaries so that they could try a peace agreement with the intruders. But this attempt became a great failure since the Fabii disrespected the right of nations and attacked the Gauls (Liv. 5.36). Taking into consideration this terrible attitude practiced by the Fabii and the imminent sack of Rome within Livy's narrative, this work will study the role of Fortuna (fortune) within the facts described in Liv.5.36-39. This paper also discusses the dishonorable behavior of the Romans, in 5.37-38, which culminated in their defeat, near the Alia River. Finally, this research focus on how Livy developed each episode in 5.39 as a regain of the Roman virtue, with examples of the courage of the Roman people and respect to the gods once disregarded. This paper also makes a study of the rhetoric and literary elements used by Livy to portray Romans and Gauls and to describe the occurred facts, as well as the analysis of some key concepts, such as fides, concordia and mos maiorum.

KEYWORDS: Livy; sack of Rome; rhetoric; morality; Fortuna.

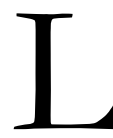

ívio compôs sua monumental obra, Ab urbe condita (Da fundação da cidade) em 142 livros, dos quais nos chegaram, além do prefácio, os livros I-X e XXI a XLV, tendo este último uma lacuna ao final. ${ }^{1}$ Dos outros livros, apenas temos inúmeros fragmentos e resumos.

Em sua obra historiográfica, Lívio preferiu acentuar o aspecto trágico da narrativa, embelezando e variando os acontecimentos de acordo com a retórica historiográfica de Cícero, mas sem deixar que essa característica se sobrepusesse aos fatos (Conte, 1999, p. 372). Assim, para Lívio a história era assunto não só de razão, mas também de emoção, e devia respeitar os acontecimentos e embelezá-los com as cores do estilo, de acordo com o que pregava Cícero. ${ }^{2}$ Por conseguinte, Lívio julgava sua história mais como uma rica atividade retórica do que uma investigação da verdade, como ele mesmo colocou no prefácio ( $(5)$ do Ab urbe cond:

Quae ante conditam condendamue urbem poeticis magis decora fabulis quam incorruptis rerum gestarum monumentis traduntur, ea nec adfirmare nec refellere in animo est.

\footnotetext{
${ }^{1}$ Desde Heródoto e Tucídides era comum o historiador escrever um proêmio antes de sua obra, com o escopo e o propósito do seu trabalho. A partir de Isócrates, esses prefácios passaram a ter grande influência da retórica, e buscavam sobretudo captar a atenção e interesse do leitor para a narrativa, como algo útil e proveitoso (Ogilvie, 1965, p. 23).

${ }^{2}$ De fato, Cícero defendia a concepção da história como historia ornata, ou história ornada, que é escrita de forma bela, com o compromisso da verdade. Daí tem-se a exigência da qualidade do estilo - em se tratando de Cícero, um estilo abundante, sem desacordos, sem paixão, mas que evidenciava as belezas da história (Martin; Gaillard, 1981, p. 115).
} 
(LÍVIO, AB URBE COND., V, 35-39)

As tradições que, antes de fundada a cidade ou de pensar-se em fundá-la, nos chegam adornadas mais pelas efabulações dos poetas do que por provas autênticas das ações realizadas, essas tradições não tenho em mente nem confirmar nem refutar. ${ }^{3}$

Lívio buscou centrar-se nas ações humanas e nas suas consequências. Além disso, uma característica marcante na historiografia latina, que também tem destaque em Lívio, era a preocupação em analisar os fatos sob o prisma das questões morais, bem como fornecer vários exempla de boas (e más) condutas. ${ }^{4}$ O próprio Lívio assim escreveu no prefácio (\$10):

Hoc illud est praecipue in cognitione rerum salubre ac frugiferum, omnis te exempli documenta in inlustri posita monumento intueri; inde tibi tuaeque rei publicae quod imitere capias, inde foedum inceptu foedum exitu quod uites.

Isto é o que há de mais salutar e fecundo no conhecimento dos feitos históricos: contemplar lições de todo tipo, postas numa obra esclarecedora; ali para ti e para tua cidade verás o que imitar, ali o que é desonroso por princípio ou em seus efeitos verás, para evitar. ${ }^{5}$

Dessa forma, os personagens de dentro do texto ensinavam aos romanos de "fora" a verdade simples e direta do que Lívio considerava como o verdadeiro valor da história: as lições deveriam ser lidas e, então, imitadas ou evitadas (Chaplin, 2000, p. 77). ${ }^{6}$ Lívio considerava que os sucessos (e fracassos) dos romanos eram fundamentalmente explicados pelos valores que os personagens representavam na narrativa dramática. Segundo Funari e Garrafoni (2016, p. 75), o prefácio já indicaria à audiência que o trabalho seria uma espécie de conjunto de ações individuais de personagens que, modeladas por Lívio, indicariam as realizações coletivas dos romanos. De fato, para Lívio, era o povo romano, mais que as instituições, que fazia a diferença nos rumos dos acontecimentos; não apenas o que o romano fazia, mas em que estado mental ele se encontrava ao agir (Luce, 1977, p. 231). Por conseguinte, Lívio preferia contar histórias que exemplificavam as virtudes romanas e os seus respectivos vícios; no livro $\mathrm{V}$, a virtude que se destaca é a pietas, e os vícios mais recorrentes são a temeritas e a ferocia (Luce, 1977, p. 231).

\footnotetext{
${ }^{3}$ Tradução de Oliva Neto (In: Martins, 2009, p. 160).

${ }^{4}$ Cícero, grande influenciador de Lívio, também ressaltava não só o caráter pragmático da história, mas igualmente a sua importância quanto ao seu papel moral, de modo a fornecer exemplos de virtude para as gerações vindouras (cf. Pro Archia, \$14-16 e Orator, \$120). Esse conceito da história como fonte de exemplos não é inovação de Cícero; de fato, Aristóteles (Retórica, 1360a) também destacou o caráter útil da história que era escrita sobre as ações dos homens, de modo a fornecer exemplos de como agir frente a problemas ou situações semelhantes aos narrados em tal gênero.

${ }^{5}$ Tradução de Oliva Neto (In: Martins, 2009, p. 160).

${ }^{6}$ Para discussão profunda sobre o papel dos exempla em Lívio recomendamos Chaplin (2000).
} 
Além disso, outro fator que desempenhou certa influência na $A b$ urbe condita foi a filosofia. Decerto que Lívio, como muitos intelectuais romanos, estudou essa matéria, e chegou a escrever diálogos filosóficos em sua juventude; dessas outras obras nada chegou aos dias de hoje, e é difícil precisar até que ponto a filosofia influenciou a escrita da história de Lívio (Usher, 2001, p. 165). O que podemos afirmar é que as exigências morais de Lívio podem ser ligadas ao Estoicismo, especialmente o conceito de Fortuna (ou Fatum), cujo episódio do saque de Roma exemplificou, nos acontecimentos narrados, o papel do destino ou sorte (André; Hus, 1974, p. 93 e 94).

Veremos mais detalhadamente esses aspectos morais e sociais a seguir, ao estudar os episódios narrados no livro V, 35-39. Realmente, observamos que os livros da primeira década possuem especial valor já que, ao contar os primeiros anos de Roma, eles "retratam o caráter inicial de construção dos elementos da identidade romana que depois apenas se reafirmam, no decurso da História dentro do texto" (Marques, 2007, p. 51).

No livro $\mathrm{V}$ de $A b$ urbe condita Tito Lívio narrou a migração dos gauleses para a Itália. ${ }^{7}$ Segundo o autor, essa migração fora motivada pela grande multidão de pessoas em seu território natal, o que levaria a uma superpopulação e também ao caos. Lívio situou esse acontecimento no reinado de Tarquínio Prisco, ou seja, por volta de 600 a.C. (Ogilvie, 1965, p. 708). Na sequência da narrativa liviana, os gauleses paulatinamente penetraram no território da Itália, e conflitos começaram a surgir. Assim, temos o seguinte trecho (V, 35):

Alia subinde manus Cenomanorum Etitouio duce uestigia priorum secuta eodem saltu fauente Belloueso cum transcendisset Alpes, ubi nunc Brixia ac Verona urbes sunt locos tenuere. Libui considunt post hos Salluuiique, prope antiquam gentem Laeuos Ligures incolentes circa Ticinum amnem. Poeninum deinde Boii Lingonesque transgressi, cum iam inter Padum atque Alpes omnia tenerentur, Pado ratibus traiecto non Etruscos modo sed etiam Vmbros agro pellunt; intra Appenninum tamen sese tenuere. Tum
Logo depois outro grupo de cenomanos, tendo por líder Etitovio, seguiu os passos dos precedentes e, com a ajuda de Beloveso, atravessou os Alpes pelo mesmo desfiladeiro; esse grupo ocupou os lugares onde hoje estão as cidades de Bríxia e Verona. Os líbuos se estabeleceram depois desses, e também os salúvios, perto da antiga tribo dos levos lígures que habitavam próximo ao rio Ticino. Em seguida, tendo os boios e os língones atravessado os Apeninos, como já estivessem ocupadas todas as terras entre o rio Pó e os Alpes, com barcos atravessaram o Pó e expulsaram da terra não só os etruscos mas também os umbros; contudo, eles se estabeleceram nos limites dos Apeninos. Então os

\footnotetext{
${ }^{7}$ Devemos aqui fazer uma breve consideração sobre os termos usados para nomear os povos da antiga Gália. César (BG., I, 1) fez distinção entre os povos que habitavam essa região, ao se referir aos belgas, aquitanos e celtas (assim chamados na língua própria deles, e em latim designados por gauleses). Neste artigo, ao conjunto das nações da Gália, vamos nos referir a todos eles indistintamente como gauleses, galos ou celtas. O termo celta era um atributo étnico, usado primeiramente pelos gregos para se referir aos povos que viviam ao norte da colônia de Marselha. Possivelmente tem ligação com a raiz kel, tendo o obscuro significado de "exaltado" ou "combativo". O termo gaulês, por sua vez, já era usado pelos romanos para se referir ao povo que veio do norte e saqueou a cidade no começo do século IV a.C. e, posteriormente, para se referir a todos os povos que possuíam linguagem e cultura célticas (Rankin, 1996, p. 1 e 2).
} 
(LÍVIO, AB URBE COND., V, 35-39)

Senones, recentissimi aduenarum, ab Vtente flumine usque ad Aesim fines habuere. Hanc gentem Clusium Romamque inde uenisse comperio; id parum certum est, solamne an ab omnibus Cisalpinorum Gallorum populis adiutam.Clusini nouo bello exterriti, cum multitudinem, cum formas hominum inuisitatas cernerent et genus armorum, audirentque saepe $\mathrm{ab}$ iis cis Padum ultraque legiones Etruscorum fusas, quamquam aduersus Romanos nullum eis ius societatis amicitiaeue erat, nisi quod Veientes consanguineos aduersus populum Romanum non defendissent, legatos Romam qui auxilium ab senatu peterent misere. De auxilio nihil impetratum; legati tres M. Fabi Ambusti filii missi, qui senatus populique Romani nomine agerent cum Gallis, 'ne, a quibus nullam iniuriam accepissent, socios populi Romani atque amicos oppugnarent. Romanis eos bello quoque, si res cogat, tuendos esse; sed melius uisum bellum ipsum amoueri, si posset, et Gallos nouam gentem pace potius cognosci quam armis'. sênones, que vieram por último, tomaram o território do rio Utente até o rio Ésis. Eu soube que foi essa a tribo que veio até Clúsio e de lá para Roma; o que parece pouco certo é se eles contaram ou não com o apoio de todos os povos da Gália Cisalpina. Os clusinos, aterrorizados com essa guerra singular, ao ver a multidão de figuras desconhecidas tanto de homens quanto de tipo de armas, e ouvindo que por várias vezes as tropas dos etruscos foram dispersadas do lado de cá e do lado de lá do Pó, enviaram emissários a Roma para que pedissem auxílio ao senado, embora não tivessem com os romanos nenhum direito de aliança ou amizade com exceção do fato de eles não terem defendido os seus parentes de Veios contra o povo romano. Sobre o auxílio, nada foi obtido; porém, foram enviados três legados, filhos de Marco Fábio Ambusto, para que em nome do senado e do povo romano tivessem com os gauleses, "para que não lutassem contra os aliados e amigos do povo romano, pois não tinham recebido deles nenhuma injúria. Pelos romanos eles seriam defendidos através da guerra, se algo se sucedesse; mas parecia melhor a própria guerra ser evitada, se pudesse, e que os gauleses, uma gente recém conhecida, fossem conhecidos mais pela paz do que pelas armas".

Lívio mencionou essas sucessivas levas migratórias dos gauleses (cenomanos, líbuos, boios, língones e os sênones) de forma condensada; de acordo com Ogilvie (1965, p. 713), esses deslocamentos ocorreram num intervalo temporal de 200 anos. Lívio para esse trecho usou como fonte Políbio (Histórias, II, 17), com algumas poucas modificações. No capítulo acima, começa a se desenrolar a ação que vai culminar na derrota dos romanos por parte dos gauleses. Abaixo, a sequência dos eventos (V, 36):

Mitis legatio, ni praeferoces legatos Gallisque magis quam Romanis similes habuisset. Quibus postquam mandata ediderunt in concilio Gallorum datur responsum, 'etsi nouum nomen audiant Romanorum, tamen credere uiros fortes esse quorum auxilium a Clusinis in re trepida sit imploratum; et quoniam legatione aduersus se maluerint quam armis tueri socios, ne se quidem pacem quam illi adferant aspernari, si Gallis
A delegação seria pacífica, se não fossem os emissários tão violentos que mais parecessem gauleses do que romanos. A eles, depois que anunciaram os assuntos ordenados no conselho dos gauleses, foi dada a seguinte resposta: "ainda que escutassem pela primeira vez o nome dos romanos, contudo acreditavam que eles eram os homens fortes aos quais pelos clusinos tenha sido implorado o auxílio em uma ocasião alarmante; como eles preferiram defender os aliados mais com uma embaixada do que com armas, na verdade eles não haveriam

\footnotetext{
${ }^{8}$ Todas as traduções do latim aqui citadas são de nossa autoria, com base no texto original editado pela Belles Lettres.
} 
egentibus agro, quem latius possideant quam colant Clusini, partem finium concedant: aliter pacem impetrari non posse. Et responsum coram Romanis accipere uelle et, si negetur ager, coram iisdem Romanis dimicaturos, ut nuntiare domum possent quantum Galli uirtute ceteros mortales praestarent'. 'Quodnam id ius esset agrum a possessoribus petere aut minari arma' Romanis quaerentibus 'et quid in Etruria rei Gallis esset', cum illi 'se in armis ius ferre et omnia fortium uirorum esse' ferociter dicerent, accensis utrimque animis, ad arma discurritur et proelium conseritur. Ibi, iam urgentibus Romanam urbem fatis, legati contra ius gentium arma capiunt. Nec id clam esse potuit, cum ante signa Etruscorum tres nobilissimi fortissimique Romanae iuuentutis pugnarent: tantum eminebat peregrina uirtus. Quin etiam Q. Fabius, euectus extra aciem equo, ducem Gallorum, ferociter in ipsa signa Etruscorum incursantem, per latus transfixum hasta occidit; spoliaque eius legentem Galli agnouere, perque totam aciem Romanum legatum esse signum datum est. Omissa inde in Clusinos ira, receptui canunt minantes Romanis. Erant qui extemplo Romam eundum censerent; uicere seniores, ut legati prius mitterentur questum iniurias postulatumque ut pro iure gentium uiolato Fabii dederentur. Legati Gallorum cum ea sicut erant mandata exposuissent, senatui nec factum placebat Fabiorum et ius postulare barbari uidebantur; sed ne id quod placebat decerneret in tantae nobilitatis uiris ambitio obstabat. Itaque, ne penes ipsos culpa esset [cladis forte Gallico bello acceptae], cognitionem de postulatis Gallorum ad populum reiciunt: ubi tanto plus gratia atque opes ualuere ut, quorum de poena agebatur, tribuni militum consulari potestate in insequentem annum crearentur. Quo facto haud secus quam dignum erat infensi Galli, bellum propalam minantes, ad suos redeunt. Tribuni militum cum tribus Fabiis creati Q. Sulpicius Longus Q. Seruilius quartum P. Cornelius Maluginensis. de recusar a paz se, aos gauleses necessitados de terra, os clusinos concedessem uma parte do território, já que eles possuiam mais terra; de outra maneira, a paz não poderia ser obtida. Desejavam receber a resposta diante dos romanos e, se a terra fosse negada, diante dos mesmos romanos eles haveriam de combater, de modo que eles pudessem anunciar à sua pátria o quanto os gauleses ultrapassavam os outros mortais em valor." Os romanos perguntaram: "que interesse tinham os gauleses na Etrúria?" Como eles respondessem ferozmente que "tinham o direito através das armas, e tudo pertencia aos homens mais fortes", dessa forma os ânimos de um e outro lado se inflamaram. Eles correram para as armas e travaram combate. Então, já estando a urbe romana próxima ao seu destino funesto, os emissários, contra o direito das nações, empunbaram as armas. Isso não pôde ser feito às escondidas, já que os três homens nobres e fortíssimos da juventude romana lutavam diante dos estandartes dos etruscos, e muito se elevava o valor estrangeiro. Ainda mais que Quinto Fábio, levado com o cavalo para além da batalha, matou o líder dos gauleses que ferozmente se lançava contra os estandartes dos etruscos, transpassando-lhe o flanco com uma lança. Os gauleses o reconheceram pegando os despojos, e por toda a batalha foi dada a notícia de ele ser o emissário dos romanos. Então a ira contra os clusinos foi deixada de lado, e eles se afastaram gritando ameaças contra os romanos. Eles estavam decididos a partir imediatamente para Roma; porém venceram os anciões, para que antes fossem enviados emissários para reclamar das injúrias e requerer que os Fábios lhes fossem entregues, devido ao direito violado das nações. Os emissários dos gauleses comunicaram esses assuntos conforme o ordenado; ao senado não agradou a ação dos Fábios, e eles reconheceram como sendo justo o pedido dos bárbaros. Contudo, a condescendência por homens de tamanha nobreza faz̧ia oposição para que não fosse decidido o que agradava ao senado. Assim, para que a culpa não caísse sobre o mesmo (caso uma guerra gaulesa causasse destruição), o senado passou para o povo a decisão sobre os pedidos dos gauleses. Como a influência e o recurso valessem mais do que o que fora discutido sobre a sua punição, eles foram eleitos tribunos militares, com poder consular, para o ano seguinte. Irritados com esse fato indigno, os gauleses, ameaçando abertamente uma guerra, voltaram para os seus. Foram eleitos tribunos militares, junto com os três Fábios, Quinto Sulpício Longo, Quinto Servílio (pela quarta vez) e Públio Cornélio Maluginense. (grifos nossos) 
No começo desse capítulo Lívio já deixou claro o desprezo com que considerava os galos, dizendo que os emissários eram tão violentos que "mais pareciam gauleses do que romanos" (Gallis magis quam Romanis similes). Podemos também ver que Lívio, ao fazer esse comentário logo no início, de certa forma já adianta o (péssimo) rumo que a situação vai tomar, uma vez que os romanos perderam sua identidade própria ao adotar uma postura que era atribuída a não romanos. ${ }^{9}$ A resposta dada pelos galos para justificar o assédio a Clúsio vai de acordo com a justificativa da questão do desejo pela terra: "aos gauleses necessitados de terra, os clusinos concedessem uma parte do território, já que eles possuíam mais terra". Essa era a explicação mais comum para as suas migrações. Os gauleses também afirmam que "ultrapassavam os outros mortais em valor" (uirtus). ${ }^{10} \mathrm{Já}$ sabendo de antemão que logo em seguida eles saqueariam Roma, podemos estabelecer uma relação do texto de Lívio com César, que dissera que os gauleses há muito tempo superavam os germanos em bravura, mas que na sua época eles tinham perdido sua uirtus. ${ }^{11}$ Lívio igualmente reforçou a ideia da crueldade desse povo, escrevendo que os gauleses apelavam para a violência, ao responder "ferozmente" (ferociter dicerent) que "tinham o direito através das armas, e tudo pertencia aos homens mais fortes" (se in armis ius ferre et omnia fortium uirorum esse).

Nesse ponto Lívio já deixou entrever o futuro sombrio de Roma, a partir do momento em que os "emissários, contra o direito das nações, empunharam as armas" (legati contra ius gentium arma capiunt). ${ }^{12}$ Assim, vislumbramos um exemplo da trágica inevitabilidade no rumo dos acontecimentos, pois ficou claro que, nesse caso, os celtas tinham o direito e a legalidade do lado deles. Lívio já sinalizou que Roma se aproximava do seu "destino funesto", embora a Fortuna (traduzida como "destino", ou "sorte") não seja citada explicitamente nesse trecho. Sobre o papel da Fortuna em narrativas latinas, seguimos a definição de Conte (1999, p. 230): a sorte apenas explica mudanças repentinas nas situações da narrativa; é um fator imponderável,

\footnotetext{
${ }^{9}$ Para se pensar em uma identidade cultural própria, geralmente é necessário definir esse conceito levando em consideração a relação - e o contraste - com o outro, como define Hartog (2009; 2014). Em contraste à identidade grega havia a identidade bárbara. O termo bárbaro, que para os helenos do período arcaico simplesmente designava os povos estrangeiros, depois se tornou sinônimo de falta de civilização, selvageria e crueldade, especialmente depois de os gregos terem vencido os persas no século V a.C. (Almeida, 2018, p. 29 e 30). Posteriormente os romanos, em contato com os gregos, adotaram vários aspectos culturais destes, dentre eles este conceito de bárbaro para se referir aos povos não romanos. Para discussão profunda sobre a identidade romana em Lívio, cf. Marques (2007). ${ }^{10} \mathrm{O}$ étimo uirtus está relacionado a uir (homem), e como destaca Pereira (1993, p. 407), wir em latim significaria "ser homem" no sentido de "ser homem direito". Virtus, comumente traduzido por virtude, também significava "valentia" ou "coragem", em princípio em sentido militar e, posteriormente, designando também a virtude de caráter (Pereira, 1993, p. 407).

${ }^{11}$ Cf. De bello Gallico (VI, 24). Lívio, narrando fatos muito recuados no tempo, escreveu que os gauleses se sobressaíam em virtude, até para justificar a derrota romana sofrida em 390 a.C. Em César, que escreveu os acontecimentos que lhe eram contemporâneos, o novo modelo de uirtus primitiva se encontrava nos germanos, e não mais nos gauleses.

${ }^{12}$ De fato, na Antiguidade clássica, os emissários e legados de guerra não podiam ser atacados; desrespeitar essa premissa era considerado um ato muito grave.
} 
ou seja, o que está além das habilidades do homem de prever e de racionalizar. O papel da sorte e do acaso na historiografia latina se deve a Políbio; "Políbio também será uma das fontes de inspiração da noção de papel decisivo do acaso (tykhé, fortuna, em latim), divindade que explica tanto as improbabilidades, como a sorte (...) (Funari; Garraffoni, 2016, p. 34).

Curioso notar que, embora os gauleses sejam retratados nessa passagem como ferozes, eles decidiram primeiramente enviar uma embaixada a Roma (como era costume das nações consideradas "civilizadas"), refreando o impulso de imediatamente rumar para atacar os romanos, mesmo com o grave desrespeito cometido pelos emissários. Os próprios senadores de Roma não gostaram da ação dos Fábios, e, como lemos acima, eles "reconheceram como sendo justo o pedido dos bárbaros". Por outro lado, como a condescendência por homens de tamanha nobreza faz̧ia oposição para que não fosse decidido o que agradava ao senado, os senadores optaram por apoiar seus concidadãos, ao se abster de assumir tal responsabilidade. Essa decisão de punir os Fábios passou para o povo; porém, como a influência e o recurso valessem mais do que o que fora discutido sobre a sua punição, os Fábios, além de não serem penalizados, ainda por cima receberam a honra de serem eleitos tribunos militares.

Podemos relacionar essa "proteção" aos Fábios como um respeito à concordia, ainda que ela tenha sido motivada pelas razões erradas, já que o senado sabia que a queixa dos gauleses era justa. De fato, a concordia (comumente traduzida por "concórdia") era um pilar moral que preconizava a união entre os romanos, a fim de preservar o bem comum (Marques, 2007, p. 69). Em si, a concordia era um conceito elevado; todavia, nesse trecho, os romanos deliberadamente desconsideraram o que era justo e, ao invés de punir os Fábios, os recompensaram. A união dos romanos, ainda que nada virtuosa nesse caso, foi mais forte do que o respeito ao que era moralmente correto; por isso, eles preferiram não punir seus concidadãos para acatar a queixa de um povo estrangeiro. Esse fato irritou ainda mais os gauleses.

Lívio então continua a narração dos acontecimentos (V, 37):

Cum tanta moles mali instaret - adeo occaecat animos Fortuna, ubi uim suam ingruentem refringi non uolt - ciuitas quae aduersus Fidenatem ac Veientem hostem aliosque finitimos populos ultima experiens auxilia dictatorem multis tempestatibus dixisset, ea tunc, inuisitato atque inaudito hoste ab Oceano terrarumque ultimis oris bellum ciente, nihil extraordinarii imperii aut auxilii quaesiuit. Tribuni quorum temeritate bellum contractum erat summae rerum praeerant, dilectumque nihilo accuratiorem quam ad media bella haberi solitus erat, extenuantes etiam famam belli, habebant. Interim Galli, postquam accepere ultro honorem habitum uiolatoribus iuris humani elusamque legationem suam esse, flagrantes ira cuius impotens est
Como tamanho mal estivesse iminente - de tal forma a Fortuna cega os ânimos, quando ela não quer que a sua vontade de agir seja reprimida - a cidade, que outrora contra os inimigos de Fidena e de Veios, e contra outros povos vizinhos, experimentando muitas calamidades, recorreu a um ditador para supremos auxílios, dessa vez, diante de um inimigo novo e estranho, que buscava a guerra vindo do oceano e dos últimos recantos das terras, não recorreu a nenhum poder extraordinário ou auxílio. Os tribunos, cuja temeridade provocou a guerra, estavam à frente do supremo comando e, considerando nada mais cuidadosamente do que já fosse o usual para as guerras comuns, menosprezaram ainda o perigo da guerra. Nesse meio tempo os gauleses, quando souberam que fora concedida tal honra aos violadores do direito das nações e, além disso, que tinha sido frustrada a sua embaixada, inflamados pela ira (que esse povo é incapaz de controlar), 
(LÍVIO, AB URBE COND., V, 35-39)

gens, confestim signis conuolsis citato agmine iter ingrediuntur. Ad quorum praetereuntium raptim tumultum cum exterritae urbes ad arma concurrerent fugaque agrestium fieret, 'Romam se ire' magno clamore significabant quacumque ibant, equis uirisque longe ac late fuso agmine immensum obtinentes loci. Sed antecedente fama nuntiisque Clusinorum, deinceps inde aliorum populorum, plurimum terroris Romam celeritas hostium tulit, quippe quibus uelut tumultuario exercitu raptim ducto aegre ad undecimum lapidem occursum est, qua flumen Allia, Crustuminis montibus praealto defluens alueo, haud multum infra uiam Tiberino amni miscetur. Iam omnia contra circaque hostium plena erant et nata in uanos tumultus gens truci cantu clamoribusque uariis horrendo cuncta compleuerant sono. imediatamente tomaram os estandartes e marcharam pelo caminho com fileira apressada. Como ao tumulto deles que passavam precipitadamente, as comunidades aterrorizadas corriam às armas e os camponeses buscavam a fuga, com grande clamor eles anunciavam "vamos a Roma". Por onde quer que passassem, com a fileira ocupavam imenso lugar, com os cavalos e tropas se espalhando em comprimento e largura. Mas mesmo antes do rumor e dos mensageiros dos clusinos, e também dos mensageiros dos outros povos, foi a rapidez dos inimigos que trouxera o terror a Roma; certamente porque o seu exército fora recrutado às pressas e, mesmo rapidamente conduzido, com dificuldade ele avançou onze milhas, até onde o rio Ália, descendo dos montes crustúmios por um canal muito profundo, se unia à corrente tiberina não muito abaixo do curso. Já todos os locais em frente e ao redor estavam repletos de inimigos e esse povo, dado a tumultos vãos, com canto cruel e vários gritos preenchiam tudo com horrendo clamor. (grifos nossos)

Mais uma vez a sorte desempenha papel importante no desenrolar da ação. De novo, é ela que justifica as mudanças repentinas nas situações narradas (favorecendo um ou outro lado), e que constitui um fator imponderável o qual, como dito antes, está além das habilidades humanas de prever os acontecimentos. Nesse trecho, então, é a "fortuna cega" que explica o fato de os romanos, mesmo diante de grande perigo, não recorrerem a um ditador ou outras medidas emergenciais, e esse trecho ecoa a passagem de V, 36, em que Roma se dirigia ao seu destino funesto. Lívio também atribuiu a culpa de tal calamidade aos próprios Fábios, “cuja temeridade provocou a guerra”, já que eles não só empunharam armas contra os gauleses quando eram emissários (indo contra o que era de direito), mas também fizeram uma péssima avaliação da situação, pois consideraram-na uma luta banal e "menosprezaram ainda o perigo da guerra". Se lembrarmos que Lívio preocupou-se em escrever uma história repleta de exemplos morais para inspirar seu público, a temeridade foi um vício que apareceu nesse capítulo para ressaltar um comportamento que deveria ser evitado pelos romanos.

Podemos novamente relacionar esse trecho ao citado anteriormente, no qual os Fábios, por causa da sua violência, pareciam-se mais com gauleses do que com romanos. Aqui, podemos observar que a falta de discernimento dos Fábios frente a tamanho perigo lembra o estereótipo do gaulês que não raciocina direito. ${ }^{13}$ Quanto à caracterização do gaulês, um tópos que Lívio citou no trecho foi o da ira, que o gaulês é incapaz de controlar. ${ }^{14}$

\footnotetext{
${ }^{13}$ César criticou a leviandade dos gauleses e afirmou que eles eram volúveis em suas decisões (BG., IV, 5).

${ }^{14}$ Sobre a ira dos gauleses, cf. César (BG., VII, 42), e Políbio (Hist., II, 35,3).
} 
A carga dramática se acentua na descrição da marcha dos celtas, em que Lívio enfatizou o alvoroço provocado por eles (“ao tumulto deles que passavam”), bem como o terror que causavam pelo seu caminho. ${ }^{15} \mathrm{De}$ fato, esse povo demonstrava na narrativa liviana um comportamento cênico na forma de agir para causar ainda mais terror nos inimigos. Temos repetição do adjetivo exterritus, usado no trecho acima para descrever as comunidades aterrorizadas (exterritae urbes) e que também apareceu em V, 35, para descrever os clusinos aterrorizados (Clusini exterriti). O capítulo termina em um suspense dramático, com vários tópoi relacionados aos gauleses, com a repetição dos tumultos que causavam, seu "canto cruel" (truci cantu) e seus vários gritos que "preenchiam tudo com horrendo clamor" (clamoribusque uariis horrendo cuncta compleuerant sono). ${ }^{16}$ No trecho acima, percebemos a figura de linguagem da acumulação - no caso, das ações que vão se sucedendo: os celtas ocuparam enorme lugar com a sua fileira e, depois que preencheram todos os locais pela frente e pelos lados, passaram a gritar para aumentar o terror. Continuamos então a narrativa (V, 38):

Ibi tribuni militum, non loco castris ante capto, non praemunito uallo quo receptus esset, non deorum saltem si non hominum memores, nec auspicato nec litato, instruunt aciem diductam in cornua ne circumueniri multitudine hostium possent; nec tamen aequari frontes poterant, cum extenuando infirmam et uix cohaerentem mediam aciem haberent. Paulum erat ab dextera editi loci quem subsidiariis repleri placuit, eaque res ut initium pauoris ac fugae, sic una salus fugientibus fuit. Nam Brennus regulus Gallorum in paucitate hostium artem maxime timens, ratus ad id captum superiorem locum ut, ubi Galli cum acie legionum recta fronte concucurrissent, subsidia in auersos transuersosque impetum darent, ad subsidiarios signa conuertit, si eos loco depulisset haud dubius facilem in aequo campi tantum superanti multitudini uictoriam fore. Adeo non fortuna modo, sed ratio etiam cum barbaris stabat. In altera acie nihil simile Romanis, non apud duces, non apud milites erat. Pauor fugaque occupauerat animos, et tanta omnium obliuio ut multo maior pars Veios in hostium urbem, cum Tiberis arceret, quam recto itinere Romam ad coniuges ac liberos fugerent.
Então os tribunos militares, sem escolber um lugar para o acampamento ou fortificar uma trincheira que serviria de refúgio, e nem ao menos se lembrando dos deuses ou dos homens, ao não tomar os auspicios on oferecer os sacrificios, colocaram em linha de batalha o exército alinhado em alas, de modo que a multidão dos inimigos não o cercasse. Contudo, não puderam igualar as alas já que, com essa disposição, a linha do meio ficou fraca e com custo se mantinha unida. Havia uma pequena elevação pelo lado direito, que os tribunos decidiram ocupar com as tropas de reserva; essa manobra, que marcou o início do pavor e da fuga, também serviu como o único meio de salvação aos desertores que debandavam. De fato Breno, comandante dos gauleses, especialmente receando um engodo devido ao pequeno número de inimigos - e avaliando que essa elevação tinha sido ocupada de modo que, no momento em que os gauleses atacassem de frente a linha reta das legiões, essas tropas reservas fizessem um ataque pelos lados e por trás - virou as suas tropas contra as de reserva. Se os expulsasse daquele lugar, sem dúvida a vitória em um terreno plano seria fácil, já que os gauleses os superavam pela maior quantidade de homens. Até esse ponto não apenas a sorte, mas também a inteligência, estava com os bárbaros. No exército contrário, não havia nada que se assemelhasse aos romanos, nem junto aos comandantes, nem junto aos soldados. O pavor e a fuga tomaram os ânimos, de tal forma que tamanho esquecimento de tudo fez com que a maiorparte

\footnotetext{
${ }^{15}$ Diodoro Sículo também falou sobre esse tumulto causado pelos gauleses (cf. Bibl., V, 30, 3).

${ }^{16}$ Esse canto cruel dos gauleses também foi mencionado por Políbio (Hist., II, 29,5) e César (BG., V, 37).
} 
(LÍVIO, AB URBE COND., V, 35-39)

Parumper subsidiarios tutatus est locus; in reliqua acie simul est clamor proximis ab latere ultimis ab tergo auditus, ignotum hostem prius paene quam uiderent, non modo non temptato certamine sed ne clamore quidem reddito, integri intactique fugerunt; nec ulla caedes pugnantium fuit: terga caesa suomet ipsorum certamine in turba impedientium fugam. Circa ripam Tiberis, quo armis abiectis totum sinistrum cornu defugit, magna strages facta est; multosque imperitos nandi aut inualidos, graues loricis aliisque tegminibus, hausere gurgites; maxima tamen pars incolumis Veios perfugit, unde non modo praesidii quicquam sed ne nuntius quidem cladis Romam est missus. $\mathrm{Ab}$ dextro cornu, quod procul a flumine et magis sub monte steterat, Romam omnes petiere et, ne clausis quidem portis urbis, in arcem confugerunt. deles fugisse para a inimiga cidade de Veios (ainda que o Tibre os retivesse) e não em direção ao reto caminho para Roma, para as suas esposas e filhos. Por pouco tempo esse local protegeu as tropas reservas; na outra linha de batalha, ao mesmo tempo foi ouvido um clamor vindo pelo lado, aos que estavam próximos, e por trás, aos que estavam distantes, a tal ponto que, sem nem ao menos ver o inimigo desconhecido, de forma alguma tentaram um combate ou sequer responderam ao grito. Eles, intactos e ilesos, fugiram, e ninguém morreu lutando: na verdade eles, feridos pelas costas, eram impedidos de fugir devido à própria briga da multidão. Em volta da margem do Tibre fugiu toda a ala esquerda, tendo atirado no rio as armas. Fez-se uma grande carnificina e muitos, incapazes de nadar pelo peso das couraças e outras proteções, ou sendo feridos, foram engolidos pelos turbilhões das águas. Todavia, a maior parte deles fugiu incólume para Veios, de onde nenbum socorro ou sequer um mensageiro da derrota foi enviado a Roma. Da ala direita, que estivera mais longe do rio e mais perto do pé do monte, todos fugiram para Roma e, nem ao menos fechando as portas da cidade, se refugiaram na cidadela. (grifos nossos)

Lívio mais uma vez ressaltou a desobediência dos Fábios ao modo tradicional de os romanos fazerem guerra, dizendo que eles foram para a batalha nem ao menos se lembrando dos deuses ou dos homens. De fato, os Fábios não escolheram um lugar para o acampamento, não fortificaram uma trincheira, não tomaram os auspícios e nem ofereceram sacrifícios aos deuses (non loco castris ante capto, non praemunito uallo, nec auspicato nec litato). ${ }^{17}$

Podemos relacionar essa postura descuidada dos Fábios à violação de dois elementos morais que regiam a sociedade romana. O primeiro deles é a pietas (comumente traduzida por "piedade"). Grosso modo, a pietas consistia no respeito e obediência aos rituais e aos deuses (Marques, 2007, p. 69). Dessa maneira, a pietas levava o cidadão romano a aceitar sua posição no mundo e a agir de acordo com ela; assim, cada um, em seu lugar, desempenharia um papel que lhe era definido, e essa era a melhor maneira de garantir a grandeza de Roma (André; Hus, 1974, p. 93). Como ressalta Usher (2001, p. 174), era a obediência à pietas que levava Roma ao seu auge moral e físico; por conseguinte, o desrespeito à pietas desagradava aos deuses e acarretava a ruína da cidade. O outro elemento moral que foi violado na narrativa, e que está profundamente ligado à pietas, é a fides (traduzida por "lealdade" ou "fidelidade"). A fides era o conceito que representava tanto a dedicação do indivíduo à coletividade da Urbe, quanto a sua lealdade aos deuses; dessa forma, fides e pietas podem ser vistas como os dois

\footnotetext{
${ }^{17}$ Os Fábios já tinham violado o direito das nações em V, 36 quando, na condição de emissários, pegaram em armas. A nova violação cometida nesse capítulo apenas reforça a causa para a derrota romana. Como destaca Ogilvie (1965, p. 716), aquela embaixada dos Fábios foi mais um pretexto psicológico e moral de Lívio para justificar o desastre de Ália. A ênfase de dizer que os Fábios se comportavam mais como gauleses do que como romanos também justifica esse acontecimento catastrófico.
} 
lados da relação entre homens e deuses, que legitima e afirma a existência e a prosperidade de Roma (Marques, 2007, p. 85). Dessa forma, ao não respeitarem a pietas e a fides, os Fábios colaboraram para os acontecimentos nefastos que levariam ao saque de Roma. ${ }^{18}$

Ademais, os Fábios imprudentemente descumpriram os princípios da pietas e da fides por infringirem o mos maiorum. De acordo com Marques (2007, p. 101), o mos maiorum não indicava exatamente uma virtude moral dos romanos (como pietas, fides, concordia, ou virtus), mas sim um conjunto de procedimentos e costumes que remetia à tradição dos antepassados. Esse "código de conduta" era regido por valores morais, e fundamentava o comportamento do cidadão romano para com seus concidadãos, Roma e os deuses. Dessa forma, através do descumprimento ao mos maiorum, os Fábios consequentemente violaram a pietas e a fides; também por causa dessa negligência, o destino trágico de Roma se delineia cada vez mais nitidamente na narrativa.

Por outro lado, vemos que os gauleses se comportaram de forma cuidadosa. Breno mostrou-se um grande estrategista, avaliando corretamente os planos dos romanos, e Lívio, reconhecendo o mérito da vitória deles, escreveu que os bárbaros, além de sorte, tiveram com eles a inteligência (adeo non fortuna modo, sed ratio etiam cum barbaris stabat). Como Rankin (1996, p. 105) pontua, a derrota terrível dos romanos foi tanto pela arrogância e descuido dos Fábios, quanto pela habilidade dos gauleses, que tinham melhor comandante.

Em seguida, temos a informação de que "no exército contrário, não havia nada que se assemelhasse aos romanos" (in altera acie nibil simile Romanis). De novo Lívio ressaltou que os romanos não se comportavam como romanos. Esse conceito, que antes fora usado para descrever os Fábios, foi alargado para descrever todos os que estavam em Ália, fossem eles líderes ou soldados (non apud duces, non apud milites). Assim, percebemos que há em Lívio uma relação direta entre o comportamento dos romanos e o sucesso da Urbe. O contrário também acontece: ao violar os valores morais e relegar o bem comum ao segundo plano, o cidadão nega sua identidade própria e age como "não romano"; com isso, ele desagrada aos deuses e atrai o fracasso individual e coletivo (Marques, 2007, p. 87-88). Lívio, sempre preocupado em ressaltar a superioridade moral e a nobreza de espírito de Roma em sua obra, usa tal expediente para frisar ainda mais o comportamento desonroso dos combatentes, que em nada se pareciam com os verdadeiros romanos ao desertarem.

Segundo Funari e Garrafoni (2016, p. 76), Lívio preconizava que os atos dos generais romanos e as narrativas de guerras deveriam ser entendidos como desdobramentos das virtudes dos romanos. Nesse caso, foi justamente a falta da virtude que trouxe grandes problemas aos romanos; mesmo se comportando de forma vergonhosa, os personagens nesse trecho fornecem exemplos a serem evitados pelo público-alvo de Lívio. Temos então várias passagens que iluminam esse fato: o "pavor e a fuga tomaram os ânimos" (pauorfugaque occupanerat animos) de tal forma que os romanos fugiram "para a inimiga cidade de Veios, ao invés de pegarem o reto caminho para Roma". Novamente temos a referência ao pânico causado pelo grito dos gauleses: "foi ouvido um clamor" (est clamor auditus). Os romanos se acovardaram a tal ponto que, "sem nem ao menos ver o inimigo desconhecido, de forma

${ }^{18}$ Para mais exemplos de respeito (ou desrespeito) à fides em Lívio, cf. Marques (2007, p. 76-85). 
alguma tentaram um combate ou sequer responderam ao grito". O desespero de correr foi tamanho que "ninguém morreu lutando", mas sim na confusão da multidão que ansiava em partir, sendo "feridos pelas costas" - o que era extremamente vergonhoso para o povo romano. A outra parte do exército, que ficara junto ao Tibre, foi massacrada ("fez-se uma grande carnificina") e muitos também morreram afogados, "incapazes de nadar pelo peso das couraças e outras proteções, ou sendo feridos, foram engolidos pelos turbilhões das águas".

Por conseguinte, como muitas dessas baixas foram causadas pela briga da multidão que fugia, e também pela malsucedida passagem do Tibre, percebemos que a terrível derrota romana foi causada mais por essa debandada desordenada do que pelo próprio confronto direto com os celtas. Lívio escreveu que "nenhum socorro ou sequer um mensageiro da derrota foi enviado a Roma", o que foi mais uma funesta consequência do pânico generalizado, também salientado pelo fato de que uma parte dos fugitivos, ao chegarem em Roma, sequer fechou as portas da cidade (ne clausis quidem portis urbis).

Toda essa descrição foi permeada de imagens fortes e grande carga patética, um traço marcante de $A b$ urbe condita. Na passagem anterior há a figura da gradação de ideias que transmitem ao público-alvo o modo como o pavor dos romanos na batalha foi paulatinamente aumentando: primeiro Lívio escreveu que os romanos não pareciam com os próprios romanos; em seguida, uma parte dos soldados, apavorada, fugiu e tomou o caminho errado que levava a Veios (e não a Roma). Depois, a tropa reserva por pouco tempo conseguiu resistir, mas, ao ouvir o grito dos gauleses, e sem sequer ver os inimigos de fato, também debandou. O ápice dessa gradação está ao final, no qual temos que os romanos morreram não pelo combate em si, mas sim pela bagunça desordenada e pela briga da própria multidão dos soldados no desespero da fuga.

Os gauleses vencedores se dirigem a Roma, como temos em V, 39:

Gallos quoque uelut obstupefactos miraculum uictoriae tam repentinae tenuit, et ipsi pauore defixi primum steterunt, uelut ignari quid accidisset; deinde insidias uereri; postremo caesorum spolia legere armorumque cumulos, ut mos eis est, coaceruare; tum demum, postquam nihil usquam hostile cernebatur, uiam ingressi, haud multo ante solis occasum ad urbem Romam perueniunt. Ubi cum praegressi equites non portas clausas, non stationem pro portis excubare, non armatos esse in muris rettulissent, aliud priori simile miraculum eos sustinuit; noctemque ueriti et ignotae situm urbis, inter Romam atque Anienem consedere, exploratoribus missis circa
O prodígio de uma vitória tão repentina deixou os gauleses de tal maneira estupefatos que, em um primeiro momento, eles mesmos ficaram imóveis de espanto, como se não entendessem o que tinha acontecido; depois, temeram uma armadilha. Por fim, recolheram os despojos dos mortos e os amontoaram em pilhas de armas, de acordo com o costume deles. ${ }^{19}$ Depois que notaram que não havia nada de hostil, avançaram pela estrada e chegaram a Roma, não muito antes do pôr do sol. Quando os cavaleiros batedores retornaram e informaram que não viram as portas fechadas, nem sentinela vigiando as entradas, e nenhum soldado a postos nas muralhas, outro prodígio (semelhante ao anterior) os conteve. Receando a noite e $o$ abandono da desconbecida cidade, eles acamparam entre Roma e o Anio, ${ }^{20}$ depois de enviar batedores ao redor das muralhas e das

\footnotetext{
${ }^{19}$ César (BG., VI, 17) já descrevera esse costume de se empilharem os despojos.

${ }^{20}$ Afluente do Tibre.
} 
moenia aliasque portas quaenam hostibus in perdita re consilia essent. Romani, cum pars maior ex acie Veios petisset quam Romam, nemo superesse quemquam praeter eos qui Romam refugerant crederet, complorati omnes pariter uiui mortuique totam prope urbem lamentis impleuerunt. Priuatos deinde luctus stupefecit publicus pauor, postquam hostes adesse nuntiatum est; mox ululatus cantusque dissonos, uagantibus circa moenia turmatim barbaris, audiebant. Omne inde tempus suspensos ita tenuit animos usque ad lucem alteram ut identidem iam in urbem futurus uideretur impetus: primo aduentu, quia accesserant ad urbem, -'mansuros enim ad Alliam fuisse nisi hoc consilii foret',deinde sub occasum solis, quia haud multum diei supererat, - 'ante noctem satius inuasuros'; - tum 'in noctem dilatum consilium esse, quo plus pauoris inferrent'; postremo lux appropinquans exanimare, timorique perpetuo ipsum malum continens fuit, cum signa infesta portis sunt inlata. Nequaquam tamen ea nocte neque insequenti die similis illi quae ad Alliam tam pauide fugerat ciuitas fuit. Nam, cum defendi urbem posse tam parua relicta manu spes nulla esset, placuit cum coniugibus ac liberis iuuentutem militarem senatusque robur in arcem Capitoliumque concedere, armisque et frumento conlato ex loco inde munito deos hominesque et Romanum nomen defendere; flaminem sacerdotesque Vestales sacra publica a caede, ab incendiis procul auferre, nec ante deseri cultum eorum quam non superessent qui colerent: 'si arx Capitoliumque, sedes deorum, si senatus, caput publici consilii, si militaris iuuentus superfuerit imminenti ruinae urbis, facilem iacturam esse seniorum relictae in urbe utique periturae turbae'. Et quo id aequiore animo de plebe multitudo ferret, senes triumphales consularesque 'simul se cum illis' palam dicere 'obituros, nec his corporibus, quibus non arma ferre, non tueri patriam possent, oneraturos inopiam armatorum'. outras portas para saber quais planos tinham os inimigos em uma situação tão desesperadora. Quanto aos romanos, a maior parte da tropa tinha fugido para Veios ao invés de Roma; ninguém acreditava que havia mais sobreviventes do que aqueles que tinham se refugiado em Roma; todos, ao mesmo tempo lastimando os vivos e os mortos, encheram toda a cidade com seus lamentos. Em seguida, o pavor generalizado se sobrepôs aos gemidos pessoais, assim que foi anunciado que os inimigos estavam porperto; logo eles ouviram os gritos e nivos dissonantes dos bárbaros, que em bandos perambulavam em volta das muralhas. A partir de então, e por todo o tempo até o dia seguinte, os ânimos se mantiveram inquietos a tal ponto que continuamente parecia que ia acontecer o ataque à cidade; primeiro, na chegada, pois eles já tinham se aproximado da cidade - "de fato teriam permanecido em Ália, se isso não fosse de seu consenso”. Depois, acharam que o ataque ia ser realizado ao pôr do sol, pois já não havia muita claridade, e "invadiriam melhor antes do cair da noite". Em seguida, consideraram que "o ataque tinha sido adiado para a noite, para causar mais pavor". Por fim, próximo ao amanhecer, ao temor geral se juntou o próprio perigo, quando as tropas hostis adentraram pelas portas. Contudo, de forma alguma durante aquela noite nem durante o dia seguinte os cidadãos se comportaram como aqueles que com tamanho pavor tinham fugido para Ália. De fato, como não havia esperança de que a cidade pudesse ser defendida pelas poucas tropas que restavam, decidiu-se então que, junto com as esposas e os filhos, a juventude militar e os senadores vigorosos se refugiariam na cidadela do Capitólio. Com armas e provisões estocadas, desse lugar fortificado eles defenderiam os deuses, os homens e o nome romano. O flamine e as sacerdotisas vestais manteriam os ritos sagrados do povo protegidos do massacre e dos incêndios, e não abandonariam o seu culto, a não ser que não existisse mais ninguém que o venerasse: "se a cidadela do Capitólio, sede dos deuses; o senado, fonte da deliberação pública; e os jovens soldados resistissem à iminente ruína da cidade, seria aceitável o sacrifício dos anciãos já que essa multidão, que fora deixada na cidade, haveria de morrer de qualquer forma". Assim, para que a multidão da plebe suportasse isso de ânimo mais calmo, os anciãos que já tinham obtido triunfos e consulados declararam publicamente que "juntamente com eles haveriam de morrer, não agravando a falta de soldados com esses corpos que não podem carregar armas e nem defender a pátria." (grifos nossos) 
Os gauleses demoraram a perceber que venceram os romanos e a partir para a urbe. O seu lento e cuidadoso avanço ("em um primeiro momento, eles mesmos ficaram imóveis; depois, temeram uma armadilha; por fim, recolheram os despojos dos mortos; depois que notaram que não havia nada de hostil, avançaram pela estrada e chegaram a Roma, não muito antes do pôr do sol") contrasta com o pânico desordenado dos romanos, que enchiam "toda a cidade com seus lamentos". Além disso, na narrativa, os celtas levaram apenas um dia para alcançar Roma; de acordo com Ogilvie (1965, p. 720), isso é uma ênfase dramática de Lívio, já que outras fontes, como Políbio (Hist., II, 18) e Diodoro (Bibl., XIV, 115), disseram que eles demoraram três dias nessa jornada. Mais uma vez fica claro que os gauleses planejaram com cuidado o que haveriam de fazer já que, "receando a noite e o abandono da desconhecida cidade, eles acamparam entre Roma e o Ânio, depois de enviar batedores ao redor das muralhas e das outras portas para saber quais planos tinham os inimigos".

Temos nova descrição de um pânico descontrolado, assim que os romanos souberam "que os inimigos estavam por perto", e temos mais uma referência aos gritos e uivos dissonantes dos gauleses (ululatus cantusque dissonos). A partir dessa chegada dos gauleses, Lívio desenvolveu cada episódio como uma etapa na restauração da moral romana, com exemplos de coragem e respeito aos deuses (Ogilvie, 1965, p. 720). Assim, ele escreve que "de forma alguma durante aquela noite nem durante o dia seguinte os cidadãos se comportaram como aqueles que com tamanho pavor tinham fugido para Ália".

O povo sabia que "não havia esperança de que a cidade pudesse ser defendida pelas poucas tropas que restavam”, e aceitou esse fato com determinação, já que se decidiu que, "junto com as esposas e os filhos, a juventude militar e os senadores vigorosos se refugiariam na cidadela do Capitólio". Ficou clara a importância dessa decisão, pois "desse lugar fortificado eles defenderiam os deuses, os homens e o nome romano. O flâmine e as sacerdotisas vestais manteriam os ritos (...) e não abandonariam o seu culto". Vemos que há uma grande preocupação em proteger os deuses, outrora desrespeitados pelos Fábios, e também a defesa do "nome romano". ${ }^{21}$ Assim, os cidadãos passaram a se comportar de forma digna, a tal ponto que poderiam retomar a designação de "romanos", que eles não honraram no fracasso em Ália. Tudo que era mais valioso para a urbe se encontrava no Capitólio, que era a "sede dos deuses: o senado, fonte da deliberação pública"; os sacerdotes e a juventude militar. Por fim, os anciões dão o exemplo supremo de honradez, aceitando morrer com a plebe, de modo a não atrapalhar a defesa da cidade.

Pode-se perceber ainda uma mudança de postura dos romanos a partir do capítulo 39, no qual eles de forma alguma haveriam de se comportar como os soldados em Ália, mas sim suportariam tudo o que estava para acontecer com coragem e bravura. Antes, no capítulo 38, os romanos haviam violado os costumes preparativos para a batalha, ao não se preocuparem em estabelecer o acampamento ou fortalecer a trincheira. Eles também violaram os ritos

${ }^{21}$ De fato, o nome romano representava, em Lívio, elevação moral e personificação da uirtus. Para discussão profunda sobre o que era ser romano, cf. o subcapítulo de Oakley, "like a Roman" (In: Mineo, 2015, p. 235-237). 
e a pietas, ao irem para a guerra sem tomar os auspícios ou oferecer sacrifícios aos deuses. No capítulo 39, fica clara a alteração de conduta: os romanos, no Capitólio, defenderiam os deuses, os homens e o seu próprio nome. ${ }^{22}$ Igualmente os sacerdotes e vestais protegeriam os cultos e não os abandonariam jamais. ${ }^{23}$ Percebemos que os romanos retomam sua fides para com os deuses e agem conforme o mos maiorum. Como Usher (2001, p. 174) destaca, era o respeito à pietas que garantia a vida saudável do corpo político e civil do Estado, além de garantir uma reserva de confiança em tempos de adversidade.

Embora Roma, na sequência da narrativa, tenha sido saqueada (restando intacto apenas o Capitólio), ${ }^{24}$ na verdade todo o episódio que começou com a violação dos Fábios aos emissários gauleses em V, 36, acabou evoluindo para a redenção de todos os romanos, a custa de grandes sofrimentos. Ao passarem por tal calamidade, respeitando os deuses e os valores da Urbe, os romanos reconquistaram a pietas; por isso, eles se tornaram merecedores do favorecimento dos deuses e da Fortuna.

Por conseguinte, na sequência do livro $\mathrm{V}$ de $A b$ urbe condita, o herói romano Camilo aparece para socorrer os romanos e derrotar os gauleses, recuperando o ouro que seria pago como resgate da Urbe. ${ }^{25} \mathrm{Em}$ V, 49, 5, Lívio fechou o giro da roda da Fortuna, dizendo: iam uerterat fortuna, iam deorum opes bumanaque consilia rem Romanam adiuuabant ("a fortuna já mudara; já a ajuda dos deuses e os planos humanos favoreciam Roma). Após o saque de Roma, temos, portanto, um novo começo para a Urbe e seus cidadãos, que ressurgem mais fortes ao aprenderem com suas falhas e derrotas. Além disso os romanos, após arcarem com as terríveis consequências de seus atos desonrosos, recuperaram seus preciosos valores morais, como a virtus e a fides.

\footnotetext{
${ }^{22}$ Marques, em seu artigo "O Capitólio como representação de Roma em Tito Lívio e Tácito" aprofunda a discussão sobre o papel do Capitólio como representação primordial do poder de Roma, e a relação dele com a construção da imagem de Roma como sendo caput mundi. De acordo com Marques (2005, p. 96), essa colina representava a ideia do destino de Roma como cidade guerreira, expansionista e conquistadora. Por esse motivo, em Lívio, essa foi a única parte da cidade que não foi invadida pelos gauleses.

${ }^{23}$ Lívio, nessa passagem, usou o termo fortuna no sentido da boa sorte concedida por uma divindade ou providência protetora a Estados ou indivíduos, geralmente em retribuição à pietas (Ogilvie, 1965, p. 708$)$.

${ }^{24}$ Os detalhes do ataque a Roma foram descritos em $A b$ urbe cond., V, 41-42. O humilhante resgate da Urbe, pago aos gauleses, encontra-se em V, 48.

${ }^{25}$ Cf. A $b$ urbe cond., V, 49.
} 
(LÍVIO, AB URBE COND., V, 35-39)

\section{REFERÊNCIAS}

ALMEIDA, Priscilla Adriane Ferreira. Os gauleses em César, Tito Livio e Plinio, o Velho: sobre a retórica da representação do outro e a construção do si. 2018. 161 f. Tese (Doutorado em Estudos Literários) - Faculdade de Letras, Universidade Federal de Minas Gerais, Belo Horizonte, 2018.

ANDRÉ, Jean-Marie; HUS, Alain. L'Histoire à Rome: historiens et biographes dans la littérature latine. Paris: Presses Universitaires de France, 1974.

CHAPLIN, Jane D. Livy's exemplary history. Oxford: Oxford University Press, 2000.

CONTE, Gian Biagio. Latin Literature: a history. Trad. Joseph B. Solodow. Baltimore: Johns Hopkins University Press, 1999.

FUNARI, Pedro Paulo A.; GARRAFFONI, Renata Senna. Historiografia: Salístio, Tito Livio e Tácito. Campinas: Ed. Unicamp, 2016.

HARTOG, François. Memória de Ulisses: narrativas sobre a fronteira na Grécia antiga. Tradução de Jacyntho Lins Brandão. 2. ed. Belo Horizonte: Editora UFMG, 2014.

HARTOG, François. O espelho de Heródoto: ensaio sobre a representação do outro. Tradução de Jacyntho Lins Brandão. Belo Horizonte: UFMG, 1999.

LUCE, T. J. Livy: the composition of his history. Princeton: Princeton University Press, 1977.

MARQUES, Juliana Bastos. O Capitólio como representação de Roma em Tito Lívio e Tácito. Caliope: presença clássica, n. 13, p. 94-109, 2005.

MARQUES, Juliana Bastos. Tradição e renovacõoes da identidade romana em Tito Livio e Tácito. 2007. 250 f. Tese (Doutorado em História Social) - Departamento de História da Faculdade de Filosofia, Letras e Ciências Humanas, Universidade de São Paulo, São Paulo, 2007.

MARTIN, René; GAILLARD, Jacques. Les genres littéraires à Rome. Paris: Nathan/ Scodel, 1981.

MARTINS, Paulo. Literatura latina. Curitiba: IESDE Brasil, 2009.

OAKLEY, Stephen P. Reading Livy's Book 5. In: MINEO, Bernard (Ed.). A companion to Livy. Oxford: Wiley-Blackwell, 2015, p. 230-41.

OGILVIE, R. M. A commentary on Livy: books 1-5. Oxford: Clarendon Press, 1965.

PEREIRA, Maria Helena da Rocha. Estudos de história da cultura clássica. 7. ed. Lisboa: Fundação Calouste Gulbenkian, 1993, v. 2.

RANKIN, David. Celts and the classical world. London: Routledge, 1996.

TITE LIVE. Histoire romaine: livre $V$. Texte établi par Jean Bayet et traduit par Gaston Baillet. Paris: Les Belles Lettres, 1954, t. 5.

USHER, Stephen. The historians of Greece and Rome. London: Bristol Classical, 2001 [1970]. 
